Pakhnenko, O., Rubanov, P., Hacar, D., Yatsenko, V., \& Vida, I. (2021).

\title{
Digitalization of financial services in European countries: Evaluation and comparative analysis
}

\section{Olena Pakhnenko}

Department of Finance, Banking and Insurance,

Sumy State University,

Ukraine

o.pak.bnenko@uabs.sumdu.edu.ua

ORCID 0000-0002-4703-4078

\section{Pavlo Rubanov}

Department of Finance and Entrepreneurship,

Sumy State University,

Ukraine

t.rubanov@finance.sumdu.edu.ua

ORCID 0000-0002-9415-8786

\section{Dusan Hacar}

Faculty of Economics and Business,

Pan-European University in Bratislava,

Slovakia

dusan.bacan@paneurouni.com

ORCID 0000-0003-4147-4547

\section{Valerii Yatsenko}

Department of Economic Cybernetics, Sumy State University,

Ukraine

v.yatsenk.0@uabs.sumdu.edu.ua

ORCID 0000-0003-2316-3817

\section{Imre Vida *}

Hungarian University of Agricukter and Life Sciences,

Doctoral School of Economics and Regional Sciences,

Hungary

info@vidaimre.com

ORCID 0000-0001-8089-9703

* Corresponding author 
Abstract. Constant innovations in finance and technology and different levels of their development worldwide necessitate investigating universal integrated indexes. It will enable a general assessment of the digitization of financial services and allow carrying out a comparative inter-nation analysis. The authors proposed to evaluate the level of digitalization of financial services (DFSI) based on three components: digital inclusion, financial inclusion, and digital financial services. The suggested approach includes several steps: 1) forming an array of input data by eight indicators; 2) establishing the priority of indicators and calculating their weights by using the Fishburne formula; 3) calculating the integral index of digitization of financial services by using the weighted sum method. According to the obtained DFSI values, the European countries were divided into four groups: with a high, medium, low, and critically low level of digitalization of financial services. Countries with a high level of DFSI are considered to be Denmark, the Netherlands, the UK, Finland, Sweden, and Norway. Most countries experience low (Greece, Hungary, Italy, Croatia, Portugal, Poland, Slovenia, Slovakia, Malta, Lithuania) or medium (Estonia, Ireland, Belgium, Latvia, Luxembourg, Germany, the Czech Republic, France, Austria, Spain) levels of DFSI. Critically low level of digitization of financial services is observed in Bulgaria, and Romania.

Keywords: financial services, digitalization, FinTech, Internet banking, mobile banking, electronic payments.

JEL Classification: G20, O33, C43

\section{INTRODUCTION}

Many scientific studies prove that innovative development is the basis for the country's economic growth and long-term welfare (Balzer et al., 2020; Kirikkaleli \& Ozun, 2019). Innovation is often seen as one of the fundamental components in ensuring the efficiency of enterprises (Bilan et al., 2020; Chigrin \& Pimonenko, 2014; Podhorska et al., 2020; Pukala et al., 2018; Zygmunt, 2019), promoting economic security and sustainable economic development of the country (Sineviciene et al., 2018). Particularly relevant is the choice of an innovative development path for transition economies, for which production, environmental and financial innovations can become a lever of competitive advantage in the international market (Bilan et al., 2019; Brychko et al., 2019; Lyulyov et al., 2021). At the same time, the nature of innovation is currently becoming quite specialized. The level of ICT adoption is increasingly crucial for the success and competitiveness of the market, as innovation is technologically driven. It is linked to the increased automation of production and general management, cloud technologies, management of large databases, etc. (Karaoulanis, 2018). Thus, there is a gradual transition to a new technological way Industry 4.0. That is why the trend of modern scientific research is to discuss topics related to Industry 4.0 and its accompanying transformations that occur in all areas of human life (Postelnicu \& Câlea, 2019).

Modern innovation is, first and foremost, the use of technologies (Kohnová et al., 2019). Their distribution has become widespread in product manufacturing and service delivery and has comprised all stages, from consumer research, production, promotion, and marketing to feedback obtaining (Ahmed et al., 2020). It is not a strange fact that e-commerce is being developed - the attention of companies has shifted to this distribution channel of goods and services, the possibility to form a competitive position 
and to meet consumer demand through electronic means has been explored (Hu et al., 2019). Moreover, digitalization has touched public administration (Balaraman, 2018), public governance (Androniceanu et al., 2020; Zarutska et al., 2018), community activities (Petrushenko et al., 2017; Petrushenko et al., 2020), capital market instruments and returns (Kozmenko \& Vasyl'yeva, 2008), financial security (Kuzmenko et al., 2020; Petroye et al., 2020; Vasylieva et al., 2020), and even social and cultural aspects of electronic communication (Beyi, 2018; Vasilyeva et al., 2020).

Indeed, such trends influence the financial system as well. In one way or another, any operation related to finance can be "upgraded" and transformed with the aim to increase its adaptability. New technologies have been emerged and appreciably changed the existing financial services (Petrushenko et al., 2018). They have created opportunities for new marketing approaches (e-banking, mobile-banking), new types of financial services (online financing through crowdfunding and peer-to-peer platforms), and also caused such a phenomenon of the digital age as cryptocurrencies (Civelek et al., 2020; Knezevic, 2018; Kohardinata et al., 2020; Kukurba \& Waszkiewicz, 2018).

The increase of financial and technological innovation has led to a growing scientific interest in this field. On the one hand, such innovations can be considered as a source of efficient improvement for the economy and the financial sector (Folwarski, 2018). They can help to align economic and business cycles, and to raise financial inclusion (Didenko et al., 2020; Gatsi, 2020; Lyeonov \& Liuta, 2016), to avoid the devastating impact of financial crises and imbalances (Brychko et al., 2021). On the other hand, unregulated use of technology in the financial sphere can have negative consequences and create additional risks, such as money laundering, data breaches, and other cyber frauds (Brychko et al., 2021; Lebid et al., 2018; Leonov et al., 2019; Lyeonov et al., 2020; Yarovenko et al., 2021). It should be noted that financial and technological innovations are often explicitly studied with respect to the segments of the financial market (Tvaronavičiené, 2019), types of financial services (Kapidani \& Luci, 2019), individual financial transactions (Adeyinka et al., 2019) or financial decision- making processes (Njegovanović, 2018; Kuzmenko \& Kyrkach, 2014).

It is defined that the level of implementation and willingness to innovate varies depending on the country and region (Carrillo, 2019; Wierzbicka, 2018), it is relevant to carry out an inter-nation comparative analysis of the financial and technological innovation development features. Existing studies demonstrate attempts to conduct international research, but most of them are based on a set of disparate indicators (Afonasova, 2019; Buriak et al., 2015; Vasilyeva et al., 2019; Kozmenko et al., 2009; Kozmenko \& Roienko, 2013). It complicates the qualitative interpretation of the obtained results, generalized assessment, and ranking countries by using the proper criterion. At the same time, the use of an index method or an integral estimation method avoids these shortcomings and makes a comparative assessment of the degree of particular economic phenomena development in different countries worldwide (Kisel'áková et al., 2018; Alikariev \& Poliakh, 2018). There are virtually no specialized studies on the financial sector among existing techniques to calculate integrated indexes of innovation and technological development (Roszko-Wójtowicz \& Białek, 2019). The most relevant studies are the FinTech Adoption Index by EY and FinTech Index by ING Economics Department. The advantages and disadvantages of using these indexes are detailed in the next section of the article.

Thereby, the scientific task to create a universal indicator that would allow evaluating and comparing the digitalization of financial services in different countries has not been solved yet. Therefore, this study aims to develop a methodology for calculating an integrated index aimed to evaluate the digitalization of financial services in the European countries and to carry out a comparative inter-nation analysis. The structure of the article includes following sections. The "Literature review" section analyzes the existing methods to calculate indexes, which can reflect the digitalization degree and FinTech innovations influence on the financial services market. The "Methodology" section provides a detailed description of 
the integrated digitalization index of financial services according to the three components (financial inclusion, digital inclusion, and digital financial services), as well as its calculation stages. The "Empirical results and discussion" section contains the calculation of the index for 28 European countries. In this section, the authors also define the range of index values, distribute them in 4 levels for qualitative results interpretation (high, medium, low, and critically low level) and compare the obtained results with the EY Fin'Tech Adoption Index.

\section{LITERATURE REVIEW}

Existing studies propose separate indicators for analyzing digital innovation development and penetration in countries worldwide. For example, in 2015, Ernst \& Young, one of the world leaders in insurance, taxation, and financial advisory services, implemented the EY FinTech Adoption Index to analyze Internet activity to use FinTech companies' services (Ernst \& Young, 2019). The company calculates the index every two years, expanding an amount of countries and types of FinTech services each time.

In another study, presented by ING Bank N.V. ("ING") in 2016, it was proposed to calculate the FinTech Index assessing the potential of low- and middle-income countries regarding the implementation of FinTech innovations (ING Economics Department, 2016).

These studies have applied different approaches to form an integrated index with the aim to estimate FinTech development. The calculation of the FinTech Adoption Index by Ernst \& Young is based on a survey of digital service users. In contrast, ING considers a person is a FinTech adopter if he or she uses two or more FinTech services.

The FinTech Adoption Index calculation was started in 2015 with a study of 6 markets (6 countries) and ten types of FinTech services within five categories: money transfers and payments; budgeting and financial planning; savings and investments; loan; insurance. The classification of services into five categories was retained in further surveys in 2017 and 2019, and the geographical scope of the study and the list of FinTech services were constantly expanding. In 2019, Ernst \& Young surveyed over 27.000 people in 27 countries worldwide using 19 types of FinTech services.

ING Bank N.V. calculates the FinTech Index as an integrated index of 3 subindexes, namely:

- urgency for financial inclusion: characterizes the relevance or need for FinTech to reach the financial services of the entire population and small and medium-sized enterprises (SMEs); it is calculated based on indicators regarding the share of population that does not have a bank account; shares of SMEs not covered by financial services; shares of poor and rural population;

- FinTech infrastructure (technology development assessment that enables to implement of FinTech services): the share of the population using mobile communications; share of Internet users; the proportion of the population connected to the electricity grid; the number of electrical outages per month;

- FinTech ecosystem: an assessment of the country's business environment for FinTech companies by the time spent on setting up a new enterprise and the Global Innovation Index.

The study also analyzes the political and regulatory environment index, which is a general feature of the country's investment climate. The country may be highly prepared to implement FinTech, has adequate infrastructure and ecosystem from the one side, but has a limited investment in FinTech caused by the unstable investment climate - from the other side (ING Economics Department, 2016).

The features of the considered approaches to assessing the digitalization level of financial services are presented in Table 1. 
Table 1

Comparative description of existing approaches to assessing the digitalization level of financial services

\begin{tabular}{|c|c|c|}
\hline \multirow{2}{*}{$\begin{array}{l}\text { Criteria for } \\
\text { comparison }\end{array}$} & \multicolumn{2}{|c|}{ Approaches } \\
\hline & FinTech Adoption Index (EY) & FinTech Index (ING) \\
\hline $\begin{array}{l}\text { The calculation } \\
\text { method }\end{array}$ & $\begin{array}{l}\text { Survey method. } \\
\text { The index is calculated by determining the } \\
\text { proportion of respondents who use two or } \\
\text { more FinTech services in the total number } \\
\text { of respondents. }\end{array}$ & $\begin{array}{l}\text { Composite index. } \\
\text { Based on three subindexes. } \\
\text { All indicators used for the calculations are } \\
\text { normalized and adjusted to values from } 0 \text { to } 10 .\end{array}$ \\
\hline $\begin{array}{l}\text { Aspects of } \\
\text { FinTech } \\
\text { development } \\
\text { considered in the } \\
\text { study }\end{array}$ & $\begin{array}{l}\text { - the category of consumers - individuals; } \\
\text { small and medium business; } \\
\text { - } 5 \text { categories and } 19 \text { types of FinTech } \\
\text { services ( } 2019 \text { survey). }\end{array}$ & $\begin{array}{l}\text { - supply, demand, and risks for the FinTech } \\
\text { development; } \\
\text { - } 3 \text { sub-indexes are calculated, each of which } \\
\text { describes a separate group of FinTech } \\
\text { development factors: the need for FinTech, } \\
\text { FinTech infrastructure, and FinTech ecosystem. }\end{array}$ \\
\hline Advantages & $\begin{array}{l}\text { - simplicity and comprehensibility of the } \\
\text { method; } \\
\text { - the most total possible consideration of } \\
\text { the financial services related to } \\
\text { technological innovation. }\end{array}$ & $\begin{array}{l}\text { - use of official statistical sources for calculation; } \\
\text { - various aspects of the analysis: supply, demand, } \\
\text { and risks for the FinTech development; } \\
\text { - calculation of subindexces allows to carry out a } \\
\text { detailed analysis of each component of FinTech } \\
\text { development. }\end{array}$ \\
\hline Disadvantages & $\begin{array}{l}\text { - the survey is conducted among internet } \\
\text { users, not the entire population; } \\
\text { - the sample survey can give a significant } \\
\text { margin of error; } \\
\text { - only one aspect of financial and } \\
\text { technological innovation introduction is } \\
\text { considered - demand among consumers for } \\
\text { FinTech start-up services. }\end{array}$ & $\begin{array}{l}\text { - the analysis is only for low- and middle-income } \\
\text { countries; } \\
\text { - FinTech is seen as a substitution by the } \\
\text { traditional banking services - for the sub-index } \\
\text { that determines the need for FinTech, the share } \\
\text { of the population without a bank account, SME } \\
\text { credit gaps, etc. are considered to be stimulants } \\
\text { for the FinTech development, contrary to the } \\
\text { results obtained in other studies. }\end{array}$ \\
\hline
\end{tabular}

Source: own compilation.

\section{METHODOLOGY}

Taking into account the advantages and disadvantages of the considered approaches to the formation of integrated indexces of FinTech and digital financial services development, the authors propose to assess the digitalization level of financial services with the Digital Financial Services Index (DFSI), which summarizes three components:

1) digital inclusion - the indicator of digitization level in society in general, refers to the penetration of digital technologies without attachment to the financial sector;

2) financial inclusion - refers to the financial services market development, indicates the general usage level of financial services;

3) digital financial services - refers to the implementation of digital technologies in providing different financial services.

Since the third group of indicators directly reflects the digitization of a particular financial service, it should be the largest. The indicators appurtenant to this group should be assigned the highest ranks in determining the weighting coefficients for the DFSI indicators. The list of indicators included in the Digital Financial Services Index is presented in Fig. 1. 


\begin{tabular}{|c|c|}
\hline Financial Inclusion Indicator & Digital Inclusion Indicator \\
\hline $\begin{array}{l}\text { ACC: the share population with the account in } \\
\text { a financial institution or mobile money }\end{array}$ & $\begin{array}{l}\text { DINC: the share of population using the } \\
\text { Internet at least once a week, } \%\end{array}$ \\
\hline \multicolumn{2}{|c|}{ Digital Financial Services Indicators } \\
\hline \multicolumn{2}{|c|}{ IBANK: the share of population (aged 16-74) using Internet banking, $\%$} \\
\hline \multicolumn{2}{|c|}{$\begin{array}{l}\text { IFA: the share of population (aged 16-74) conducting other financial transactions (insurance, } \\
\text { securities, etc.) via the Internet, } \%\end{array}$} \\
\hline \multicolumn{2}{|l|}{ ECOM: the e-commerce share in total sales, $\%$} \\
\hline \multicolumn{2}{|c|}{ EPAY: the share of population $(15+$ years $)$ conducting electronic payments, $\%$} \\
\hline \multicolumn{2}{|c|}{ MOB: the share of population (15+ years), who use mobile phones to pay bills, $\%$} \\
\hline alternative & unding, peer \\
\hline
\end{tabular}

Figure 1. The structure of the Digital Financial Services Index (DFSI)

Source: own compilation.

The values of most indicators selected to calculate an integrated index of digitization of financial services are published in official statistical databases regularly, particularly in the World Bank and Eurostat databases (Table 2).

Table 2

Data sources for DFSI indicators

\begin{tabular}{|l|l|}
\hline \multicolumn{1}{|c|}{ DFSI indicators } & \multicolumn{1}{c|}{ Data sources } \\
\hline ACC & Global Financial Inclusion Database, the World Bank \\
\hline DINC, IBANK, IFA, ECOM & Eurostat \\
\hline EPAY, MOB & Global Financial Development Database, the World Bank \\
\hline ALTF & Cambridge Centre for Alternative Finance; the World bank \\
\hline
\end{tabular}

Source: own compilation.

For raising the digitalization of financial services, both financial and digital inclusion of consumers are essential. We've chosen the most general indicators for this criteria. The financial inclusion component is taken into account by indicating the share of respondents who has an account (individual or shared) in the bank or another type of financial institution or uses the mobile money service for the last 12 months.

The digital inclusion component reflects the share of the population who uses the Internet regularly, i.e., at least once a week, during the last three months before the survey. The criterion of using the Internet to calculate this indicator includes all access methods (computer, mobile phone, personal digital assistant, gaming machine, digital television, etc.) and any purpose (private or related to work/business).

The IBANK indicator characterizes the share of the population using Internet banking. It considers all the respondents' transactions with the bank, which are carried out in electronic form (for example, payment of bills), and receiving information about the account status. 
The next indicator of the DFSI is the share of the population who conducts other financial transactions via the Internet (IFA). It takes into account at least one of the following financial transactions via the Internet during the reporting period:

- sale or purchase of shares, bonds, other investment assets and obtaining other investment services via the Internet;

- the purchase or renewal of existing insurance policies, including those offered as part of bundled services (e.g., travel insurance provided with a plane ticket) via the Internet;

- obtaining a loan or making a loan at a banking or other financial institutions via the Internet.

The e-commerce indicator (ECOM) characterizes the share of enterprises' cash revenues from the sale of products through electronic networks in the total volume of sales over the last 12 months.

The share of the population making electronic payments (EPAY) reflects the percentage of respondents who used electronic means to pay bills or purchase goods (including payments made personally by respondents through using the money on accounts and automatic payments) over the last 12 months. Another indicator representing digital financial services is the percentage respondents who used a mobile phone to pay their bills in the previous 12 months.

The last indicator to evaluate the level of digitalization of financial services is the share of traditional loan replacement with alternative online financing (ALTF). This indicator is proposed to be calculated as a share of alternative online financing in the total private sector lending. The total amount of alternative financing includes the sum of all loans attracted by individuals and legal entities through online platforms in the form of peer-to-peer loans, crowdfunding, balance loans, and more. Private-sector lending includes all financial resources provided to the private sector (households, private enterprises, and in some countries also public enterprises) by financial corporations (banks, financial and leasing companies, credit unions, insurance companies, pension funds, etc.) through loans, commercial credits, debt securities purchase, financing of receivables, etc.

The digitalization level of financial services is proposed to calculate using the linear mathematical model of the integrated indicator (weighted sum method) according to the formula (1):

$$
\begin{gathered}
D F S I=w_{\text {acc }} \cdot A C C+w_{\text {dinc }} \cdot D I N C+w_{\text {ibank }} \cdot I B A N K+w_{\text {ifa }} \cdot I F A+w_{\text {ecom }} \cdot E C O M \\
+w_{\text {epay }} \cdot E P A Y+w_{\text {mob }} \cdot M O B+w_{\text {altf }} \cdot A L T F
\end{gathered}
$$

where $w_{i}$ is a weighting coefficient of $\mathrm{i}$-indicator of the DFSI.

In order to establish the weighting coefficients for the variables selected as indicators of the Digital Financial Services Index, we apply the Fishburn formula (formula (2)):

$$
w_{i}=\frac{2 \cdot(n-i+1)}{n \cdot(n+1)}
$$

where

$n$ - the total number of indicators for evaluating the digitalization of financial services;

$i$ - the rank of an indicator in assessing the digitalization level of financial services.

The Fishburn formula in calculating weighting coefficients allows to determine the indicators' significance based on their ranking. It is used in cases where it is sufficient to know only the degree of 
preference for one indicator compared to others, which is fully consistent with the objectives of this study.

Thus, the calculation of the DFSI includes the following steps:

1) to form an array of input data by eight indicators;

2) to define the weighting coefficients of the indicators according to the Fishburn formula;

3) to calculate the integrated index of digitalization of financial services by weighted sum method.

Let us note that due to the use of only relative indicators as indicators expressed in percentages or fractions of a unit, there is no need to normalize the indicators.

\section{EMPIRICAL RESULTS AND DISCUSSION}

Starting the practical implementation of the proposed approach to assessing the digitalization of financial services, we form an array of input data from eight indicators. Given the constraints of the availability of statistics for individual countries and periods of study, a group of countries to calculate an integrated index of digitalization of financial services includes 28 countries in the European region. The selected indicators, defined as components of the integrated index, are relative values, which can be expressed in fractions (with values from 0 to 1 ) and in percentages (range of possible values from $0 \%$ to $100 \%$ ). We've chosen the percentage view of the analyzed indicators. An array of input data was generated for 2016-2019 to ensure comparability of the used indicators (Table 3).

The next step is aimed to calculate the weighting coefficients for the indicators regarding the integrated index of digitalization of financial services. To achieve this, we need to determine the priority of each indicator.

The highest priority is given to the share of the population who uses Internet banking (IBANK). Banking services are in high demand among the general public and business entities. Usually, banking services sales volume is more significant relatively to other types of financial services. Financial and technological innovations are spread in the fastest way in the banking sector and make the first indicator of digitalization of financial services.

In its turn, the share of the population who conducts other financial transactions (transactions with securities, insurance services) over the Internet (IFA) is the second priority in the integrated index. The digitalization of these financial services is also one of the most critical components of digital financial services in general. Still, unlike banking services, the demand for insurance services and securities brokerage services is not so massive, and, as a rule, there is a less frequent need for these services.

The third priority is given to payment transactions. This component includes all types of payments made over the Internet using a personal computer or mobile application, either through a financial institution or with the participation of traditional intermediaries. In calculating the integrated index, payment transactions are represented by two indicators - the proportion population making electronic payments (automatic and online) (EPAY) and the proportion of the population using a mobile phone to pay bills (MOB). An equal priority is set for both indicators.

The next highest priority is the indicator of the traditional loans replaced with alternative online financing (ALTF). It describes the next digitalization level of financial services where information technologies are not used only to change the way of distribution of financial services and their improvement but also to transform financial intermediation by replacing traditional financial institutions with online platforms. As this level of transformation of the financial sector is not typical for all world countries, the relevant indicator can only be considered an additional factor with lower priority. 
Table 3

Input data to calculate the integrated index of digitalization of financial service (fragment for 2019)

\begin{tabular}{|c|c|c|c|c|c|c|c|c|}
\hline \multirow{2}{*}{ Country } & \multicolumn{8}{|c|}{ Indicators, $\%$} \\
\hline & ACC & DINC & IBANK & IFA & ECOM & EPAY & MOB & ALTF \\
\hline Austria & 98.2 & 86.0 & 63.0 & 9.0 & 14.0 & 93.5 & 8.5 & 0.0040 \\
\hline Belgium & 98.6 & 89.0 & 71.0 & 12.0 & 33.0 & 96.3 & 22.7 & 0.0143 \\
\hline Bulgaria & 72.2 & 67.0 & 9.0 & 4.0 & 4.0 & 41.2 & 2.3 & 0.0000 \\
\hline Croatia & 86.1 & 77.0 & 46.0 & 5.0 & 12.0 & 75.1 & 13.5 & 0.0000 \\
\hline The Czech Republic & 81.0 & 85.0 & 68.0 & 16.0 & 32.0 & 76.4 & 10.4 & 0.0107 \\
\hline Denmark & 99.9 & 95.0 & 91.0 & 25.0 & 25.0 & 98.5 & 18.5 & 0.0051 \\
\hline Estonia & 98.0 & 88.0 & 81.0 & 50.0 & 14.0 & 94.4 & 11.1 & 0.2218 \\
\hline Finland & 99.8 & 93.0 & 91.0 & 39.0 & 23.0 & 98.1 & 25.1 & 0.0316 \\
\hline France & 94.0 & 87.0 & 66.0 & 12.0 & 22.0 & 89.5 & 6.1 & 0.0150 \\
\hline Germany & 99.1 & 91.0 & 61.0 & 21.0 & 15.0 & 96.5 & 5.7 & 0.0103 \\
\hline Greece & 85.5 & 74.0 & 31.0 & 5.0 & 4.0 & 56.6 & 3.6 & 0.0000 \\
\hline Hungary & 74.9 & 80.0 & 47.0 & 11.0 & 24.0 & 61.7 & 2.7 & 0.0000 \\
\hline Ireland & 95.3 & 88.0 & 67.0 & 40.0 & 34.0 & 91.2 & 13.1 & 0.0000 \\
\hline Italy & 93.8 & 74.0 & 36.0 & 8.0 & 12.0 & 86.2 & 4.7 & 0.0022 \\
\hline Latvia & 93.2 & 84.0 & 72.0 & 30.0 & 7.0 & 83.1 & 9.1 & 0.1216 \\
\hline Lithuania & 82.9 & 81.0 & 65.0 & 20.0 & 13.0 & 67.0 & 5.0 & 0.0000 \\
\hline Luxembourg & 98.8 & 93.0 & 71.0 & 13.0 & 14.0 & 96.8 & 9.2 & 0.0000 \\
\hline Malta & 97.4 & 85.0 & 54.0 & 14.0 & 13.0 & 79.3 & 6.3 & 0.0000 \\
\hline Netherlands & 99.6 & 95.0 & 91.0 & 43.0 & 15.0 & 96.9 & 17.9 & 0.0142 \\
\hline Norway & 99.7 & 98.0 & 95.0 & 46.0 & 26.0 & 98.9 & 29.9 & 0.0003 \\
\hline Poland & 86.7 & 78.0 & 47.0 & 7.0 & 18.0 & 79.0 & 8.9 & 0.0043 \\
\hline Portugal & 92.3 & 73.0 & 42.0 & 10.0 & 19.0 & 81.2 & 5.4 & 0.0000 \\
\hline Romania & 57.8 & 72.0 & 8.0 & 2.0 & 7.0 & 32.7 & 3.3 & 0.0000 \\
\hline Slovakia & 84.2 & 82.0 & 55.0 & 10.0 & 21.0 & 75.9 & 5.2 & 0.0064 \\
\hline Slovenia & 97.5 & 81.0 & 47.0 & 8.0 & 17.0 & 89.9 & 6.1 & 0.0000 \\
\hline Spain & 93.8 & 88.0 & 55.0 & 11.0 & 17.0 & 88.2 & 7.2 & 0.0038 \\
\hline Sweden & 99.7 & 95.0 & 84.0 & 50.0 & 25.0 & 97.5 & 30.5 & 0.0022 \\
\hline The UK & 96.4 & 95.0 & 78.0 & 56.0 & 31.0 & 94.2 & 18.2 & 0.1252 \\
\hline
\end{tabular}

Source: own calculation.

The share of e-commerce in total sales is the indicator that has the most indirect impact on the digitalization level of financial services. The demand for financial assistance in e-commerce usually arises when handling accounts and financial transactions. The share of e-commerce shows the level of digitalization of the economy as a whole. Still, in the case of financial services, this indicator is indirect and, therefore, it will have the least priority among the indicators of digital financial services determining the weighting coefficient.

Indicators representing the financial and digital inclusion (ACC and DINC) reflect only a single aspect of digitalization of financial services, i.e., either digital or financial service extension criteria. Consequently, they will have the lowest priority among all analyzed indicators. As for the priority between 
the two components, it must be equal since the level of technological and information development and the demand for financial services are equally important for the digitalization of financial services.

According to the above considerations, it is possible to establish the following system of inequalities between the indicators of assessing the digitalization of financial services by their priority (formula (3)):

$$
w_{\text {ibank }}>w_{\text {ifa }}>w_{\text {epay }}=w_{\text {mob }}>w_{\text {altf }}>w_{\text {ecom }}>w_{\text {acc }}=w_{\text {dinc }}
$$

Based on the given system of inequalities between the weighting coefficient, we can determine their ranks and calculate their values by the formula (2). The results are presented in table 4 .

Table 4

Ranks and values of the weighting coefficients of DFSI indicators

\begin{tabular}{|l|c|c|c|c|}
\hline \multicolumn{1}{|c|}{ Indicator } & Priority & Rank & Weight of indicator, fraction & Weight of indicator, $\%$ \\
\hline ACC & 6 & 7.5 & 0.04167 & 4.167 \\
\hline DINC & 6 & 7.5 & 0.04167 & 4.167 \\
\hline IBANK & 1 & 1 & 0.22222 & 22.222 \\
\hline IFA & 2 & 2 & 0.19444 & 19.444 \\
\hline ECOM & 5 & 6 & 0.08333 & 8.333 \\
\hline EPAY & 3 & 3.5 & 0.15278 & 15.278 \\
\hline MOB & 3 & 3.5 & 0.15278 & 15.278 \\
\hline ALTF & 4 & 5 & 0.11111 & 11.111 \\
\hline
\end{tabular}

Source: own calculation.

Depending on the priority of each of the eight indicators, they are assigned a proper rank from 1 to 8. It is necessary to take into account the equality of priorities of some indicators. The figures of the population who conducts electronic payments (automatic and online) and the population who uses mobile phones for paying bills occupy the $3^{\mathrm{d}}$ and $4^{\text {th }}$ positions with equal priority, so they are assigned an equal rank - 3.5. Similarly, indicators regarding the account in a financial institution or mobile money provider and the share of the population using the Internet receive equal rank -7.5 . Thus, substituting the defined ranks of indicators in the Fishburn formula, we obtain the weighting coefficients in the percentages and fractions.

Taking into account the obtained weighting coefficients, we calculate the integrated index of the digitalization of financial services for European countries by the formula (1). The results for 2016 and 2019 are presented in Fig. 2.

Most European countries increased the level of digitization of financial services during the period 2016-2019. The Netherlands and Scandinavian countries (Denmark, Finland, Sweden, and Norway) have the highest digitalization level of financial services (53-60\%) both in 2016 and 2019. The United Kingdom and Ireland achieved the highest increase of the DFSI for the period (from $48.3 \%$ to $56.0 \%$, and from $40.8 \%$ to $49.1 \%$, respectively). 


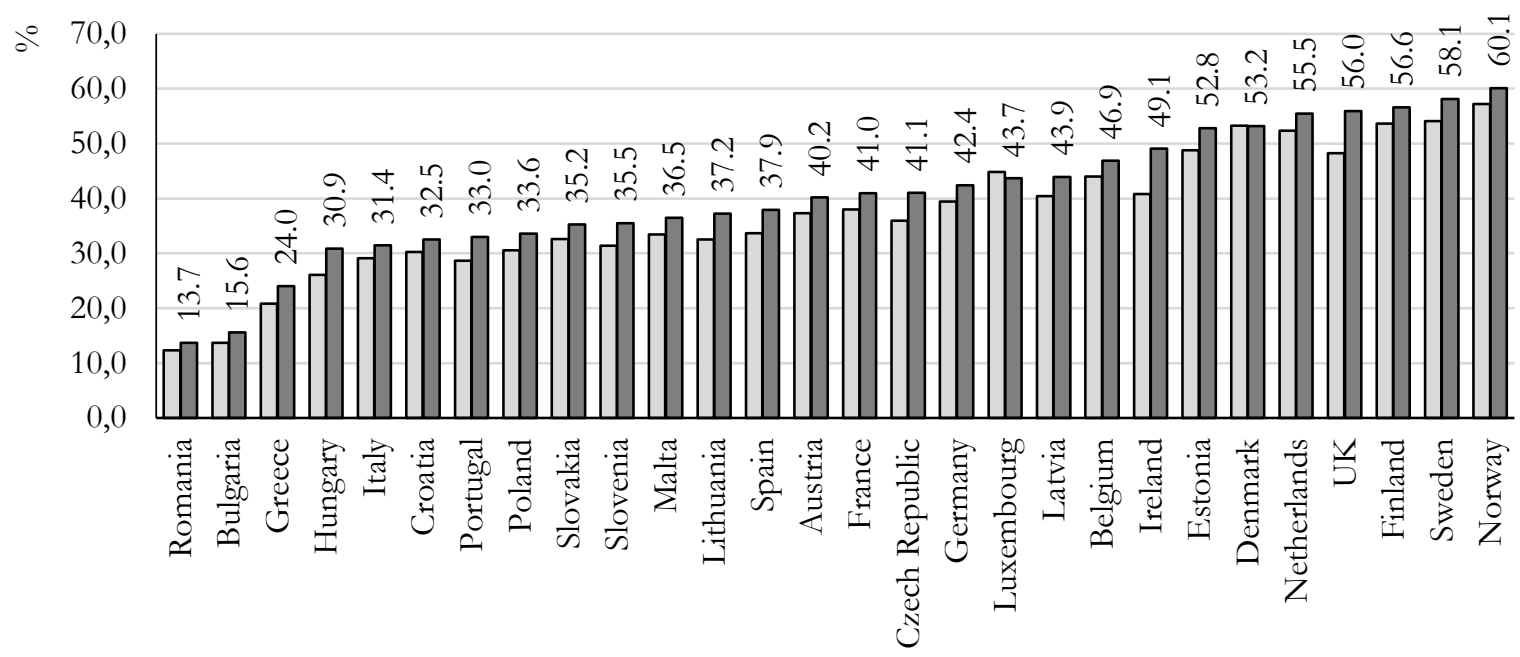

$\square 2016 \square 2019$

Figure 2. Results for calculation of DFSI in European countries, \% Source: own compilation.

The lowest digitalization level of financial services (13-15\%) is in Romania and Bulgaria. Despite the positive dynamics, they lag far behind other European countries in the digitalization level of financial services.

Mathematically, the interval of possible values of the calculated integrated index of digitalization of financial services, expressed in fractions, is $[0 ; 1]$ (or $[0 ; 100]$ when expressed as a percentage). However, to establish scientifically sound limiting values for the index and qualitatively interpret the obtained results, it is necessary to define the minimum and maximum values of each component of the integrated index for the studied sample of countries and to adjust it by the magnitude of the average linear deviation towards the decrease or increase respectively for the minimum and maximum value (Table 5).

Table 5

Limiting values of the integrated index of digitalization of financial services

\begin{tabular}{|l|c|c|c|c|c|c|c|c|c|}
\hline \multicolumn{1}{|c|}{ Indicators } & ACC & DINC & IBANK & IFA & ECOM & EPAY & MOB & ALTF & DFSI \\
\hline Minimum value of the sample 0 & 57.8 & 56.0 & 4.0 & 2.0 & 4.0 & 32.7 & 2.3 & 0.00 & $\mathrm{X}$ \\
\hline Maximum value of the sample 0 & 99.9 & 98.0 & 95.0 & 56.0 & 35.0 & 98.9 & 30.5 & 0.22 & $\mathrm{X}$ \\
\hline Average linear deviation 0 & 7.9 & 8.8 & 18.6 & 10.6 & 5.4 & 13.1 & 6.4 & 0.03 & $\mathrm{X}$ \\
\hline The lower limit) & 49.9 & 47.8 & 0.0 & 0.0 & 0.0 & 19.6 & 0.0 & 0.00 & 7.06 \\
\hline The higher limit 0 & 100.0 & 100.0 & 100.0 & 68.3 & 41.2 & 100.0 & 36.9 & 0.25 & 68.23 \\
\hline
\end{tabular}

Source: own calculation.

Thus, the values of the integrated index of digitalization of financial services are in the range of $7 \%$ to $68 \%$. In order to give a qualitative interpretation of the results, we divide the obtained range $[7,68]$ into 4 equal intervals $([7 ; 22) ;[22 ; 37,5] ;[37,5 ; 53] ;[53 ; 68])$. Extending the boundaries of extreme intervals to mathematically possible values $(0 \%$ and $100 \%)$, we obtain the following gradation of financial services digitalization levels (Table 6). 
Qualitative interpretation of the DFSI values

\begin{tabular}{|l|c|c|c|c|}
\hline \multirow{2}{*}{} & \multicolumn{3}{|c|}{ The range of values of the DFSI, \% } \\
\cline { 2 - 5 } & {$[0 ; 22)$} & {$[22 ; 37.5)$} & {$[37.5 ; 53)$} & {$[53 ; 100]$} \\
\hline $\begin{array}{l}\text { Qualitative interpretation of } \\
\text { digitalization of financial } \\
\text { services }\end{array}$ & Critically low & Low & Medium & High \\
\hline
\end{tabular}

Source: own compilation.

Therefore, countries with a high digitalization level of financial services include six countries: all analyzed Scandinavian countries (Norway, Denmark, Finland, Sweden), the United Kingdom, and the Netherlands. The UK moved to the top countries with the highest digitalization level of financial services in 2019. One of the favorable factors for this is that the state policy is aimed to actively support FinTech innovation and digitalization. The smallest group is countries with a critically low digitalization level of financial services: Bulgaria and Romania. The sample of countries for analysis was made of European countries, most of which are highly economically developed and have a high digitalization level. Most countries have a medium digitalization level of financial services: Estonia, Ireland, Belgium, Latvia, Luxembourg, Germany, the Czech Republic, France, Austria, and Spain. The rest of the studied countries are described by low digitalization level of financial services.

We compared the obtained results from the Digital Financial Services Index calculation with other similar indexes, particularly the FinTech Adoption Index by Ernst \& Young (Ernst \& Young, 2019). The sample of countries is determined by the availability of data on the FinTech Adoption Index. The results are presented in Fig. 3.

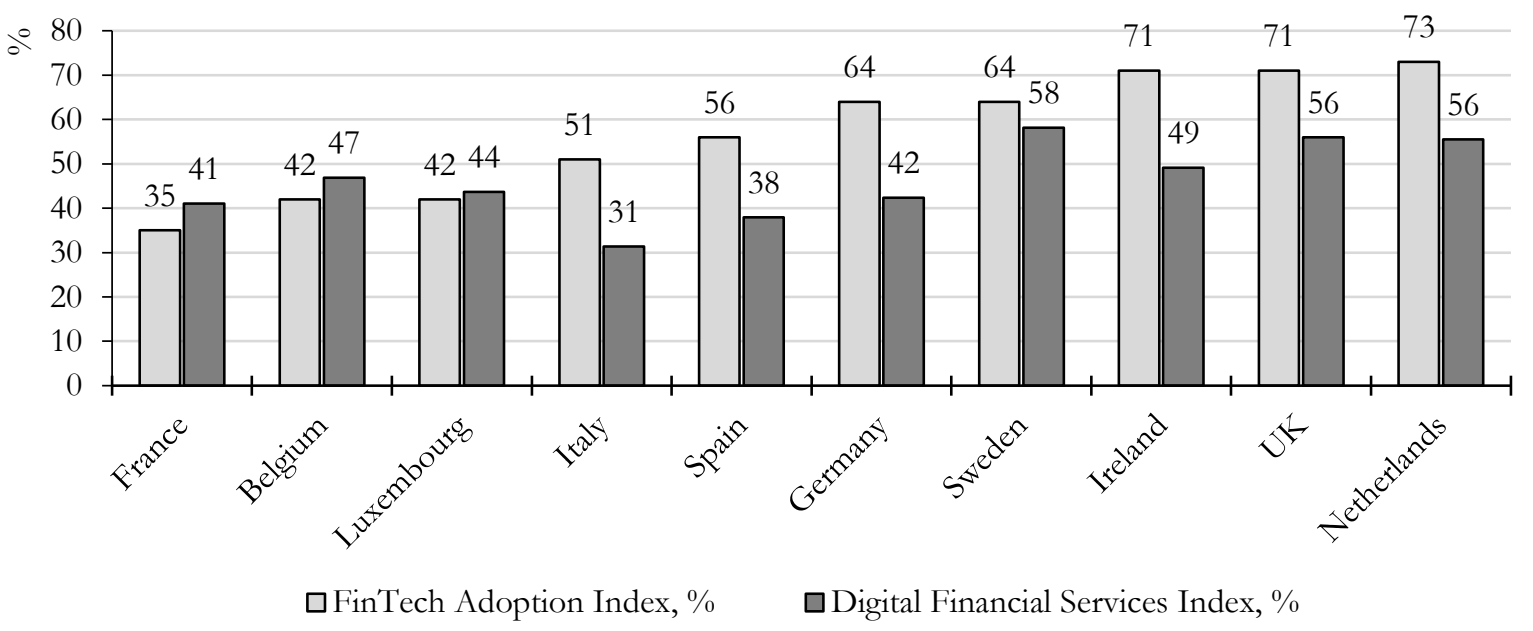

Figure 3. Digital Financial Services Index and FinTech Adoption Index in 2019

Source: own compilation.

According to Fig. 3, there are significant differences in the Digital Financial Services Index and FinTech Adoption Index results for European countries in 2019. In most of the analyzed countries, the FinTech Adoption Index is much higher than the digitalization level of financial services, except for France, Belgium, and Luxembourg. The high values of the FinTech Adoption Index indicate the growing 
popularity of FinTech services in recent years and their use by a significant proportion of Internet users (according to the methodology of the index). At the same time, the digitalization level of various types of financial services and financial transactions has significant differences. It varies from a high level of electronic payments and online banking to relatively low values of e-commerce and digitalization of other types of financial services.

\section{CONCLUSION}

The paper proposes a method for calculating the integrated index of digitalization of financial services (DFSI) using the weighted sum method for eight indicators based on three components (financial inclusion, digital inclusion, and digital financial services). To give the qualitative interpretation of the integrated index, four ranges of its values are set with critically low, low, medium, or high digitalization level of financial services. During 2016-2019, the digitalization level of financial services had increased in most European countries. In 2019 the high digitalization level of financial services had been reached by six countries, including Norway, Denmark, Finland, Sweden, the UK, and the Netherlands. The countries where the digitalization of financial services is critically low are Bulgaria and Romania. The largest groups are countries with low and medium digitalization level of financial services. In particular, countries with a medium level of financial service technologization include ten countries: Estonia, Ireland, Belgium, Latvia, Luxembourg, Germany, the Czech Republic, France, Austria, and Spain. Countries with low digitalization levels of financial services also include ten countries: Greece, Hungary, Italy, Croatia, Portugal, Poland, Slovenia, Slovakia, Malta, and Lithuania. Financial market participants and national regulatory authorities can use the obtained results to develop measures to stimulate and oversee innovative technology implementation in financial activities.

\section{ACKNOWLEDGEMENT}

The article was executed in the framework of state budget scientific research works: "Data-Mining for Countering Cyber Fraud and Money Laundering in the Context of Digitalization of the Financial Sector of the Ukrainian Economy" (Registration No. 0121U100467), and "National Security Through the Convergence of Financial Monitoring Systems and Cybersecurity: Intelligent Modeling of Financial Market Regulation Mechanisms" (Registration No. 0121U109559).

\section{REFERENCES}

Adeyinka, Ad. J., Daniel, Ad. Ad., \& Adeniyi, D. J. (2019). An Assessment of the Relationship Between the Volume and Value of ICT Transactions in the Nigerian Deposit Money Banks: 2007-2017. Financial Markets, Institutions and Risks, 3(1), 30-42. doi: http://doi.org/10.21272/fmir.3(1).30-42.2019.

Afonasova, M.A., Panfilova, E.E., Galichkina, M.A., \& Ślusarczyk, B. (2019). Digitalization in Economy and Innovation: The Effect on Social and Economic Processes. Polish Journal of Management Studies, 19 (2): 22-32. doi: 10.17512/pjms.2019.19.2.02

Ahmed, R. R., Romeika, G., Kauliene, R., Streimikis, J., \& Dapkus , R. (2020). ES-QUAL model and customer satisfaction in online banking: evidence from multivariate analysis techniques. Oeconomia Copernicana, 11(1), 59-93. doi:10.24136/oc.2020.003

Alikariev, O.F.U., \& Poliakh, S. (2018). Index of protection of the interests of consumers of the financial services market. Business Ethics and Leadership, 2(1), 78-95. doi: 10.21272/bel.2(1).78-95.2018

Androniceanu, A., Kinnunen, J., Georgescu, I. (2020). E-Government clusters in the EU based on the Gaussian Mixture Models. Administratie si Management Public, 35, 6-20. doi: 10.24818/amp/2020.35-01

Balaraman, P. (2018). ICT and IT Initiatives in Public Governance - Benchmarking and Insights from Ethiopia. Business Ethics and Leadership, 2(1), 14-31. doi: 10.21272/bel.2(1).14-31.2018 
Balzer, R., Užík, M., \& Glova J. (2020). Managing growth opportunities in the digital era - an empiric perspective of value creation. Polish Journal of Management Studies, 21 (2), 87-100. doi:10.17512/pjms.2020.21.2.07

Beyi, W. A. (2018). The Trilogy of a Digital Communication between the Real Man, His Digital Individual and the Market of the Digital Economy. SocioEconomic Challenges, 2(2), 66-74. doi: 10.21272/sec.2(2).66-74.2018

Bilan, Y., Pimonenko, T., \& Starchenko, L. (2020). Sustainable business models for innovation and success: Bibliometric analysis. Paper presented at the E3S Web of Conferences, 159. doi:10.1051/e3sconf/202015904037

Bilan, Y., Vasilyeva, T., Kryklii, O., \& Shilimbetova, G. (2019). The creative industry as a factor in the development of the economy: Dissemination of European experience in the countries with economies in transition. [Kūrybinè industrija kaip ekonomikos pletros veiksnys: Europietiškosios patirties sklaida pereinamojo laikotarpio ekonomikos šalyse] Creativity Studies, 12(1), 75-101. doi:10.3846/cs.2019.7453

Brychko, M., Bilan, Y., Lyeonov, S., \& Mentel, G. (2021). Trust crisis in the financial sector and macroeconomic stability: A structural equation modelling approach. Economic Research-Ekonomska Istrazivanja, 34(1), 828-855. doi:10.1080/1331677X.2020.1804970

Brychko, M., Polách, J., Kuzmenko, O., \& Olejarz, T. (2019). Trust cycle of the finance sector and its determinants: The case of Ukraine. Journal of International Studies, 12(4), 300-324. doi:10.14254/2071-8330.2019/12-4/20

Brychko, M., Savchenko, T., Vasylieva, T., \& Piotrowski, P. (2021). Illegal activities of financial intermediaries: A burden of trust crisis. Journal of International Studies, 14(1), 172-189. doi:10.14254/2071-8330.2021/14-1/12

Buriak, A., Lyeonov, S., \& Vasylieva, T. (2015). Systemically important domestic banks: An indicator-based measurement approach for the Ukrainian banking system. Prague Economic Papers, 24(6), 715-728. doi:10.18267/j.pep. 531

Carrillo, M. (2019). Measuring and ranking R\&D performance at the country level. Economics and Sociology, 12(1), 100114. doi: https://doi.org/10.14254/2071-789X.2019/12-1/5

Chigrin, O., \& Pimonenko, T. (2014). The ways of corporate sector firms financing for sustainability of performance. International Journal of Ecology and Development, 29(3), 1-13. Retrieved from https://www.scopus.com/record/display.uri?eid=2-s2.0-84904394388\&origin=resultslist

Civelek, M., Gajdka, K., Světlík, J., \& Vavrečka, V. (2020). Differences in the usage of online marketing and social media tools: evidence from Czech, Slovakian and Hungarian SMEs. Equilibrium. Quarterly Journal of Economics and Economic Policy, 15(3), 537-563. doi:10.24136/eq.2020.024

Didenko, I., Paucz-Olszewska, J., Lyeonov, S., Ostrowska-Dankiewicz, A., \& Ciekanowski, Z. (2020). Social safety and behavioral aspects of populations financial inclusion: A multicountry analysis. Journal of International Studies, 13(2), 347-359. doi:10.14254/2071-8330.2020/13-2/23

Ernst\&Young (2019). EY FinTech Adoption Index 2019. Retrieved from https://www.ey.com/en_gl/ey-globalfintech-adoption-index

Folwarski, M. (2018). The impact of selected regulations on the development of payments systems in Poland. Marketing and management of innovations, 3, 302-312. doi: 10.21272/mmi.2018.3-27

Gatsi, J. G.(2020). Effects of International and Internal Remittanaces on Financial Inclusion in Ghana. Financial Markets, Institutions and Risks, 4(3), 109-123. doi: https://doi.org/10.21272/fmir.4(3).109-123.2020

ING Economics Department (2016). The FinTech Index: Assessing digital and financial inclusion in developing and emerging countries. Retrieved from https://www.ing.nl/media/ING_EBZ_fintech-index-report_tcm162-116078.pdf

Hu, X., Ocloo, C. E., Akaba, S., \& Worwui-Brown, D. (2019). Effects of business to business e-commerce adoption on competitive advantage of small and medium-sized manufacturing enterprises. Economics and Sociology, 12(1), 80-99. doi:10.14254/2071-789X.2019/12-1/4

Kapidani, M., \& Luci, E. (2019). The Effects on Innovation from Financial Sector Development: Evidence from Developing Countries. Journal of Competitiveness, 11(2), 84-94. doi: https://doi.org/10.7441/joc.2019.02.06

Karaoulanis, A. (2018). Big Data, What Is It, Its Limits and Implications in Contemporary Life. Business Ethics and Leadership, 2(4), 108-114. doi: http://doi.org/10.21272/bel.2(4).108-114.2018.

Kirikkaleli, D., \& Ozun, A. (2019). Innovation capacity, business sophistication and macroeconomic stability: empirical evidence from OECD countries. Journal of Business Economics and Management, 20(2), 351-367. doi:https://doi.org/10.3846/jbem.2019.9602 
Knezevic, D. (2018). Impact of Blockchain Technology Platform in Changing the Financial Sector and Other Industries. Montenegrin Journal of Economics, 14(1), 109-120. doi:: 10.14254/1800-5845/2018.14-1.8

Kohardinata, C., Suhardianto, N., \& Tjahjadi, B. (2020). Peer-to-Peer lending platform: from substitution to complementary for rural banks. Business: Theory and Practice, 21(2), 713-722. doi: https://doi.org/10.3846/btp.2020.12606

Kohnová, L., Papula, J., \& Salajová, N. (2019). Internal factors supporting business and technological transformation in the context of Industry 4.0. Business: Theory and Practice, 20: 137-145. doi: https://doi.org/10.3846/btp.2019.13

Kozmenko, O., Merenkova, O., \& Boyko, A. (2009). The analysis of insurance market structure and dynamics in Ukraine, Russia and European insurance and reinsurance federation (CEA) member states. Problems and Perspectives in Management, 7(1), 29-39. doi:10.21511/ppm.7(1).2009.01

Kozmenko, O., \& Roienko, V. (2013). Evaluation and use of indicators of insurance companies' investment activities. Investment Management and Financial Innovations, 10(3), 98-105. doi:10.21511/imfi.10(3).2013.01

Kozmenko, S., \& Vasyl'yeva, T. (2008). Specialized innovative investment banks in Ukraine. Banks and Bank Systems, 3(1), 48-56. doi:10.21511/bbs.3(1).2008.01

Kukurba, M., \& Waszkiewicz, A. (2018). Crowdfunding as a Form of Funding for Businesses in the CulturallyChanging Global Economy: A Literature Review. Journal of Intercultural Management, 10(2), pp.99-137. doi:10.2478/joim-2018-0011

Kunesova, H., \& Micik, M. (2019). Developing Composite Readiness and Intensity Indices for Measuring B2C Ecommerce in the European Union. Transformations in Business \& Economics, 18(1), 44-59. Retrieved August 20, 2019, from http://www.transformations.knf.vu.lt/46/rp46.pdf

Kuzmenko, O., \& Kyrkach, S. (2014). The use of regression analysis in the financial planning of banks, mathematical formalization of the stages of financial planning in banks. Banks and Bank Systems, 9(1), 120-126. Retrieved from https://www.scopus.com/record/display.uri?eid=2-s2.0-84960896914\&origin=resultslist

Kuzmenko, O., Šuleř, P., Lyeonov, S., Judrupa, I., \& Boiko, A. (2020). Data mining and bifurcation analysis of the risk of money laundering with the involvement of financial institutions. Journal of International Studies, 13(3), 332-339. doi:10.14254/2071-8330.2020/13-3/22

Lebid, O., Chmutova, I., Zuieva, O., \& Veits, O. (2018). Risk assessment of the bank's involvement in legalization of questionable income considering the influence of fintech innovations implementation. Marketing and Management of Innovations, 2, 232-246. doi: http://doi.org/10.21272/mmi.2018.2-19

Leonov, S., Yarovenko, H., Boiko, A., \& Dotsenko, T. (2019). Information system for monitoring banking transactions related to money laundering. CEUR Workshop Proceedings, 2422, 297-307. Retrieved from https:/ /www.scopus.com/record/display.uri?eid=2-s2.0-85071081226\&origin=resultslist

Lyeonov, S., \& Liuta, O. (2016). Actual problems of finance teaching in Ukraine in the post-crisis period. The financial crisis: Implications for research and teaching, 145-152. doi:10.1007/978-3-319-20588-5_07

Lyeonov, S., Żurakowska-Sawa, J., Kuzmenko, O., \& Koibichuk, V. (2020). Gravitational and intellectual data analysis to assess the money laundering risk of financial institutions. Journal of International Studies, 13(4), 259272. doi:10.14254/2071-8330.2020/13-4/18

Lyulyov, O., Paliienko, M., Prasol, L., Vasylieva, T., Kubatko, O., \& Kubatko, V. (2021). Determinants of shadow economy in transition countries: Economic and environmental aspects. International Journal of Global Energy Issues, 43(2-3), 166-182. Retrieved from https://www.scopus.com/record/display.uri?eid=2-s2.085106862529\&origin=resultslist

Njegovanović, A. (2018). Digital Financial Decision With A View Of Neuroplasticity / Neurofinancy / Neural Networks. Financial Markets, Institutions and Risks, 2(4), 82-91. doi: http://doi.org/10.21272/fmir.2(4).8291.2018

Petroye, O., Lyulyov, O., Lytvynchuk, I., Paida, Y., \& Pakhomov, V. (2020). Effects of information security and innovations on Country's image: Governance aspect. International Journal of Safety and Security Engineering, 10(4), 459-466. doi:10.18280/ijsse.100404 
Petrushenko, Y., Kostyuchenko, N., Smolennikov, D., \& Vorontsova, A. (2017). Impact of the participatory financing of international development projects on social capital of the local communities. Problems and Perspectives in Management, 15(3), 183-192. doi:10.21511/ppm.15(3-1).2017.02

Petrushenko, Y., Kozarezenko, L., Glinska-Newes, A., Tokarenko, M., \& But, M. (2018). The opportunities of engaging FinTech companies into the system of crossborder money transfers in Ukraine. Investment Management and Financial Innovations, 15(4), 332-344. doi:10.21511/imfi.15(4).2018.27

Petrushenko, Y., Vadym, A., Vorontsova, A., \& Ponomarenko, O. (2020). Sustainable development goals as a tool for strategic planning in communities: A bibliometric analysis of research. Paper presented at the E3S Web of Conferences, 202. doi:10.1051/e3sconf/202020203005

Podhorska, I., Vrbka, J., Lazaroiu, G., \& Kovacova, M. (2020). Innovations in Financial Management: Recursive Prediction Model Based on Decision Trees. Marketing and Management of Innovations, 3, $276-292$. doi:10.21272/mmi.2020.3-20

Postelnicu, C., \& Câlea, S. (2019). The Fourth Industrial Revolution. Global Risks, Local Challenges for Employment. Montenegrin Journal of Economics 15(2), 195-206. doi:10.14254/1800-5845/2019.15-2.15

Pukala, R., Sira, E., \& Vavrek, R. (2018). Risk management and financing among Start-ups. Marketing and Management of Innovations, (3), 153-161. doi:10.21272/mmi.2018.3-13

Roszko-Wójtowicz, E., \& Białek, J. (2019). Measurement of the average innovativeness change over time in the EU member states. Journal of Business Economics and Management, 20(2), 268-293. doi: https://doi.org/10.3846/jbem.2019.8337

Sineviciene, L., Shkarupa, O., \& Sysoyeva, L. (2018). Socio-economic and Political Channels for Promoting Innovation as a Basis for Increasing the Economic Security of the State: Comparison of Ukraine and the Countries of the European Union. SocioEconomic Challenges, 2(2), 81-93. doi: 10.21272/sec.2(2).81-93.2018

Tvaronavičienè, M. (2019). Insights into global trends of capital flows' peculiarities: emerging leadership of China. Administratie si Management Public, 32, 6-17. doi: 10.24818/amp/2019.32-01

Vasilyeva, T., Kuzmenko, O., Bozhenko, V., \& Kolotilina, O. (2019) Assessment of the dynamics of bifurcation transformations in the economy. CEUR Workshop Proceedings, 2422, 134-146. Retrieved from https://www.scopus.com/record/display.uri?eid=2-s2.0-85071124329\&origin=resultslist

Vasilyeva, T., Bilan, S., Bagmet, K., \& Seliga, R. (2020). Institutional development gap in the social sector: Crosscountry analysis. Economics and Sociology, 13(1), 271-294. doi:10.14254/2071-789X.2020/13-1/17

Vasylieva, T., Jurgilewicz, O., Poliakh, S., Tvaronavičienè, M., \& Hydzik, P. (2020). Problems of measuring country's financial security. Journal of International Studies, 13(2), 329-346. doi:10.14254/2071-8330.2020/13-2/22

Wierzbicka, W. (2018). Information infrastructure as a pillar of the knowledge-based economy - an analysis of regional differentiation in Poland. Equilibrium. Quarterly Journal of Economics and Economic Policy, 13(1), 123-139. doi: 10.24136/eq.2018.007

Yarovenko, H., Bilan, Y., Lyeonov, S., \& Mentel, G. (2021). Methodology for assessing the risk associated with information and knowledge loss management. Journal of Business Economics and Management, 22(2), 369-387. doi:10.3846/jbem.2021.13925

Zarutska, E., Pavlova, T., \& Sinyuk, A. (2018). Structural-functional analysis as innovation in public governance (case of banking supervision). Marketing and Management of Innovations, 4, 349-360. doi:10.21272/mmi.2018.4-30

Zygmunt, A. (2019). External linkages and intellectual assets as indicators of firms' innovation activities: results from the Czech Republic and Poland. Oeconomia Copernicana, 10(2), 291-308. doi:10.24136/oc.2019.015 